\title{
Editorial: Journal of Shipping and Trade
}

CrossMark

\author{
T.C. Edwin Cheng, Y.H. Venus Lun ${ }^{*}$ and K.H. Lai
}

\author{
* Correspondence: \\ venus.lun@polyu.edu.hk \\ Shipping Research Centre, The \\ Hong Kong Polytechnic University, \\ Hong Kong, Hong Kong
}

Journal of Shipping and Trade (JST) is an open access and multi-disciplinary academic journal that focuses both shipping business and transport related areas. Shipping is closely associated with trading activities. JST aims to promote best practices in shipping and to facilitate global trade activities. JST provides a platform for academics and policy makers in the shipping and trade related fields to disseminate research findings and to share the work with others. As a scholarly journal emphasizing shipping and trade related studies, $J S T$ is important in establishing communication links among global researchers. JST also aims to contribute to current and emerging issues in shipping and trade as raised by global and regional public bodies (e.g., AIIB, ASEAN, UNCTAD, and World Bank).

The first batch of research articles publishing in JST include the inaugural article and the articles of two JST's special issues. The inaugural article aims to examine the economic impact of transport complex economies (TCEs). TCEs comprise both upstream and downstream firms in the transport chain that conduct shipping and trade-related activities, which can be desirable locations for port users to perform their business activities. To explore TCEs, the authors build a theoretical model to illustrate the relationship between trade facilitation activities and trade costs. The economic outcomes are also examined in the theoretical model. The TCE model is empirically validated by data collected from the World Bank. The findings illustrate the importance of the development of social capital for trade facilitation.

The first special issue of $J S T$ is the thematic series on "Environmental Impact of Shipping". The Guest Editors are Thierry Vanelslander and Edwin van Hassel of the University of Antwerp. The first three papers examine emission: the first paper deals with economic impact valuation of environmental impacts of shipping emissions, the second paper looks into low-emission engine technologies in response to environmental shipping regulations, and the third paper makes an economic evaluation of operational strategies for shipping emissions. The fourth paper takes a combined macromicro approach to compare forecast aggregate demand for LNG with company-level operational strategies. The fifth paper develops an economic model on marine dredging sediments. The final paper provides a concrete application on operational strategy by analysing the impact of slow steaming. With this combination of papers, the special issue provides a snapshot of economic analysis of shipping environmental impacts.

Another special issue of JST to be published is the thematic series on "Connecting the World through Global Shipping Networks". The editorial team members include Jan Hoffmann (United Nations Conference on Trade and development), Gordon Wilmsmeier (Economic Commission for Latin America and the Caribbean), and

(C) 2016 The Author(s). Open Access This article is distributed under the terms of the Creative Commons Attribution 4.0 International License (http://creativecommons.org/licenses/by/4.0/), which permits unrestricted use, distribution, and reproduction in any medium, provided you give appropriate credit to the original author(s) and the source, provide a link to the Creative Commons license, and indicate if changes were made. 
Venus Lun (Hong Kong Polytechnic University). This thematic series aims to publish high-quality research papers that employ a variety of rigorous and pertinent research methodologies supported with empirical evidence to examine the challenges of global shipping connectivity. Broad themes focus on alternative measures of connectivity, describing and explaining the structure of maritime shipping networks, and analyzing the impact of connectivity on international trade.

Published online: 20 July 2016

Submit your manuscript to a SpringerOpen ${ }^{\odot}$ journal and benefit from:

- Convenient online submission

- Rigorous peer review

- Immediate publication on acceptance

- Open access: articles freely available online

- High visibility within the field

- Retaining the copyright to your article

Submit your next manuscript at $>$ springeropen.com 